\title{
ВПЛИВ МЕДСЕСТРИНСЬКОГО ДОГЛЯДУ У ПОДОЛАННІ ДЕПРЕСИВНИХ СТАНІВ ПАЦІЄНТІВ ХОСПІСУ
}

\author{
О. В. Іванчук, К. Н. Слободенюк, А. О. Боб \\ Бериславський медичний коледж \\ Херсонська обласна лікарня "Хоспіс» \\ ДВНЗ «Тернопільський державний медичний університет \\ імені І. Я. Горбачевського МОЗ Украӥни” \\ ННІ медсестринства
}

\begin{abstract}
Сестринський персонал відіграє ключову роль в організації паліативної допомоги. Медична сестра має великі можливості налагодити психологічний контакт із пацієнтом, що сприятиме адекватному і організованому догляду. Медсестринський догляд, як один із складових хоспісної допомоги, допомагає виявити депресивні стани та вчасно контролювати їх. Когнітивно-поведінкову психотерапію вважають пріоритетним способом, який полягає в навчанні хворого вміння контролювати власні емоції, мислення, поведінку.
\end{abstract}

\section{NURSING INFLUENCE IN THE OVERCOMING OF DEPRESSIVE STATES OF THE HOSPICE PATIENTS}

\author{
O. V. Ivanchuk, K. N. Slobodenyuk, A. O. Bob \\ Beryslav Medical College \\ Kherson Regional Hospital «Hospice» \\ I. Horbachevsky Ternopil State Medical University \\ Educational-Scientific Institute of Nursing, Ternopil
}

\begin{abstract}
Nursing staff plays a key role in the organization of palliative care. The nurse has great opportunities to establish psychological contacts with the patient, which will promote adequate and organized care. Nursing care, as one of the components of hospice care, helps to detect depression and control it in time. Cognitive-behavioral psychotherapy is considered as a priority method, which means to teach the patient of the ability to control their emotions, thoughts, and behavior.
\end{abstract}

Вступ. Медичній сестрі необхідно володіти інформацією про психоемоційний стан пацієнта, адже паліативна допомога - це складна, активна, комплексна допомога невиліковно хворій людині, що охоплює пацієнтів, сім'ю та громаду, має за мету збереження найвищої якості життя пацієнта. Усвідомлення пацієнтом власної тяжкої хвороби, несприятливий перебіг захворювання із загрозою для життя пацієнта викликає розвиток нозогенної депресії [ 3].

Депресія - це стан зниженого настрою з домінуванням емоцій астенічного полюса (апатія, тривога, страх, смуток). Депресивний стан вважають патологічним тоді, коли не виявлено його специфічної психологічної причини або коли сам стан триває надто довго і його симптоми $\epsilon$ тяжкими [5]. Розглядати депресію як

(с) О. В. Іванчук, К. Н. Слободенюк, А. О. Боб, 2017 хворобу можливо лише в тому випадку, коли зміна настрою відносно фіксована, є стійкою протягом 2-х і більше тижнів та позначається на поведінці, мисленні, діяльності всього організму.

Існує соматогенна депресія, пов'язана з хворобливими відчуттями через соматичне захворювання. Соматичне захворювання $\epsilon$ безпосередньою причиною депресії, прискорює розвиток депресії при наявності відповідної схильності [2]. Депресія може розвинутися як реакція на тяжке соматичне захворювання, яке зумовлене низкою психологічних, соціальних, особистісних, біологічних факторів, що містять об'єктивні параметри порушення рівня здоров'я [6]. Посилює депресію фізичний дискомфорт: біль, обмеження рухової активності, дефіцит самодогляду тощо. 
Основними завданнями медичної сестри в наданні допомоги інкурабельному пацієнтові $є:$ динамічний контроль больового синдрому, контроль симптомів (анорексія, кахексія, нудота, блювання, запаморочення, запор, діарея, безсоння, сплутаність свідомості людини і т. д.); профілактика ускладнень, що пов'язані з гіподинамією; психологічна підтримка пацієнта і членів його сім'ї.

Медична сестра може виявити психологічні проблеми пацієнта, зокрема депресивні стани, через спостереження за пацієнтом, бесіду, фізичне обстеження, збір та аналіз суб'єктивних та об'єктивних даних.

Дослідження суб'єктивного відчуття депресії проводили у 2017 р. на базі Херсонської обласної лікарні «Хоспіс». Всього було обстежено 20 пацієнтів. Відбір пацієнтів здійснювали за рівнем функціональних можливостей до спілкування.

Ми здійснили всебічну оцінку стану пацієнта та застосували холістичний підхід щодо надання медичної та психологічної допомоги. 3 метою визначення депресивних станів і станів, близьких до депресії, було застосовано опитувальник Зунге (в адаптації Т. І. Балашової) [4]. Опитувальник розроблений для диференційної діагностики депресивних станів і ста- нів, близьких до депресії, для скринінг-діагностики при масових дослідженнях і з метою попередньої, долікарської діагностики. Повне тестування з обробкою займає 40-60 хв. Якщо рівень депресії не більше 50 балів, то діагностують стан без депресії. Якщо рівень депресії більше 50 і менше 59 балів, тоді робиться висновок про легку депресію ситуативного чи невротичного генезу. Показник рівня депресії від 60 до 69 балів - субдепресивний стан або маскована депресія. Істинний депресивний стан діагностують при рівні депресії більше 70 балів.

Метою даного дослідження було виявити напрямки покращення підготовки студентів медичного коледжу до майбутньої волонтерської діяльності, зокрема у хоспісі, через вивчення особливостей психологічного стану пацієнтів, які уже отримують волонтерський догляд.

Основна частина. У ході спостереження за пацієнтами медичні сестри відзначили такі симптоми, як: сум, байдужість, втома, порушення сну, порушення апетиту, апатія, невпевненість у собі, відчуття неадекватності, розчарування і безпорадності. Ці ознаки вказують на появу депресивних явищ. Стан без депресії виявлено лише в одного пацієнта, що свідчить про стійкий психоемоційний стан (рис. 1).

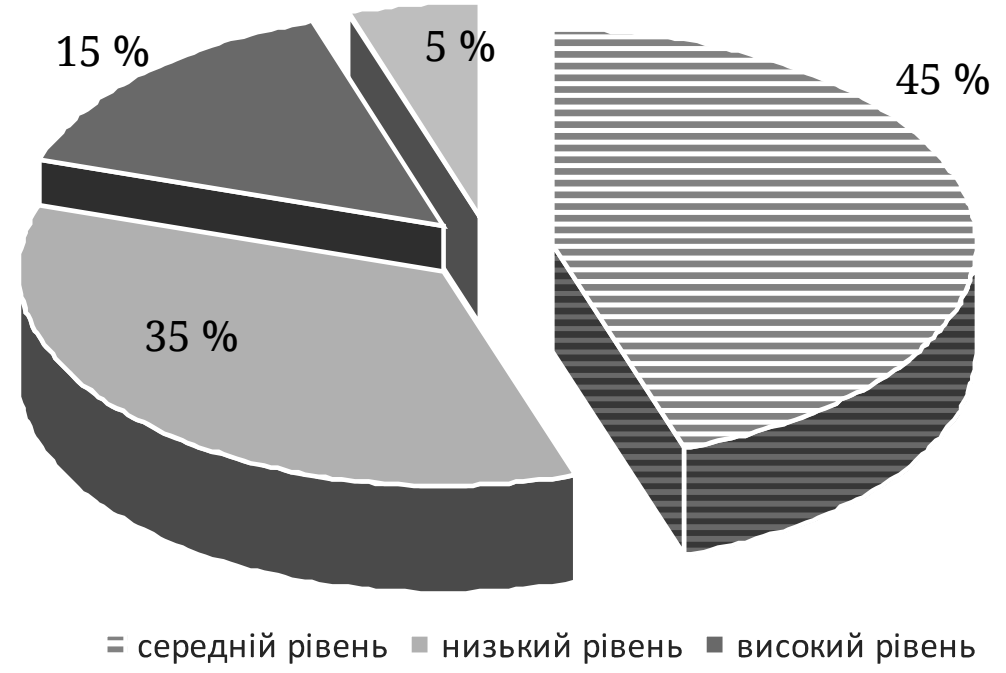

\section{Рис. 1. Розподіл рівня відчуття депресивності у пацієнтів Херсонської обласної лікарні «Хоспіс».}

У результаті дослідження виявлено, що у вибірці переважає субдепресивний стан або маскована депресія (45 \%), рівень легкої депресії відзначають у 35 \% опитаних. Істинний депресивний стан спостерігають у $15 \%$ пацієнтів. Стан без депресії становить $5 \%$. Отже, у пацієнтів, які спілкуються із волонтерами і отримують хоспісну допомогу, переважають легкі форми депресивних розладів (табл. 1).
Варто звернути увагу на варіанти маскованої депресії, яку в даному випадку спостерігають найчастіше. Депресія має місце під маскою різноманітної соматовегетативної симптоматики, а прояви депресії можуть бути нетиповими.

Під час першого огляду хворих із маскованою депресією складається враження, що психомоторна загальмованість у них відсутня (ознака в тому чи ін- 
Таблиця 1. Результати діагностики депресивних станів і станів, близьких до депресії, пацієнтів Херсонської обласної лікарні «Хоспіс»

\begin{tabular}{|l|c|c|c|c|}
\hline \multicolumn{1}{|c|}{ Рівень депресії } & $\begin{array}{c}\text { Стан без } \\
\text { депресії }\end{array}$ & $\begin{array}{c}\text { Легка ситуаційна депресія } \\
\text { (невротичного ґенезу) }\end{array}$ & $\begin{array}{c}\text { Маскована } \\
\text { депресія }\end{array}$ & $\begin{array}{c}\text { Істинний депресив- } \\
\text { ний стан }\end{array}$ \\
\hline Кількість обстежених осіб & 1 & 7 & 9 & 3 \\
\hline $\begin{array}{l}\text { Частка обстежених у від- } \\
\text { сотках }\end{array}$ & 5 & 35 & 45 & 15 \\
\hline $\begin{array}{l}\text { Середній за групою рі- } \\
\text { вень депресії у балах }\end{array}$ & 45,0 & 53,9 & 68,7 & 71,3 \\
\hline
\end{tabular}

шому ступені властива для будь-якої форми депресії). Такі хворі, як правило, багатомовні, часто самостійно звертаються до лікарів, дещо нав'язливі в своїх скаргах, до того ж їм особливо часто здається, що їх недостатньо добре зрозуміли, не хочуть вислуховувати. Хворі схильні до деталізації переживань, вкрай іпохондричні, емоційно-лабільні, занепокоєні можливою динамікою розвитку захворювання [3].

Будь-яка хвора людина потребує особливої, підвищеної уваги й турботи. Людина ж, яка зазнає сильного болю і душевних страждань від усвідомлення наближення смерті, стає занадто сприйнятливою та вразливою, може виявляти роздратування або злість. Біль може повністю знищити людину як особистість. Він спричиняє нестерпні страждання хворому й нерідко деформує його психіку [1]. Тому, надаючи допомогу для полегшення фізичного стану паліативним пацієнтам необхідно звертати особливу увагу на психологічну реакцію пацієнта на свій стан. Медична сестра повинна вміти виявити і враховувати ці особливості хворого при спілкуванні та наданні допомоги.

Психологічний стрес від наявності невиліковного захворювання, особисті й соціальні проблеми при наявності у хворих психічних порушень надзвичайно ускладнюють їхнє життя. Поряд із проблемами соціальної ізоляції не менш значимими в плані формування реактивних психічних розладів $\epsilon$ й проблеми, пов'язані з невиліковною хворобою, що розвивається, і тривалістю життя, що залишилося. Працюючи з такими пацієнтами, медичні сестри роблять все можливе для того, щоб покращити якість життя пацієнта із депресивними станами. Здійснюють догляд, допомагають іти на прогулянку, читають художню та релігійну літературу, розповідають суспільні та соціальні новини.

Психологічною проблемою, з якою стикаються хворі, єїхня соціальна ізоляція [4]. У них зменшується кількість спілкування із сім'єю, трапляються випадки, коли від них відмовляються родичі й друзі. Навіть у хоспісі пацієнти можуть відчувати «стіну» між собою й зовнішнім світом. На нашу думку, доцільно навчати медичних сестер та волонтерів навичок активного слухання, стилю спілкування, який характеризується як центрований на пацієнтів підхід.

Традиційно вважалося, що паліативна допомога починається виключно з того моменту, коли стає очевидно, що смерть хворого неминуча. Зараз прийнято вважати, що паліативна допомога повинна починатися на більш ранніх стадіях захворювання, що прогресує. Вона використовує всі медичні втручання, які $\in$ в її арсеналі, серед них $є$ і засоби, спрямовані на боротьбу із захворюванням, заходи психологічної підтримки пацієнта та його родини.

Висновки. Депресія - це афективний стан людини, який, як правило, супроводжується загальною пасивністю поведінки, негативним емоційним фоном, когнітивними уявленнями, змінами мотиваційної сфери. Людина, яка перебуває в такому стані, відчуває болісні, тяжкі, негативні переживання та емоції тугу, пригніченість, безвихідь, відчай. У такому стані у людини зазвичай різко знижуються всі потреби, бажання, мотиви, потяги, вольова активність. Нами було доведено, що найбільш очевидними ознаками депресії $є$ тужливий настрій, а також переживання пригніченості, самотності або апатії.

У пацієнтів, які спілкуються із волонтерами i отримують хоспісну допомогу, переважають легкі та скриті форми депресивних розладів. Ознаки депресії виявлені не у всіх пацієнтів. Отже, вважаємо роботу медичних сестер як одну із складових хоспісної допомоги, доцільною, її потрібно розвивати. Психологічна освіта $є$ одним із важливих завдань підготовки середніх медичних працівників. Тяжкохворим потрібен особливий догляд та увага. Когнітивно-поведінкову психотерапію вважають пріоритетним способом, який полягає в навчанні хворого вміння контролювати власні емоції, мислення, поведінку. 


\section{СПИСОК ЛІТЕРАТУРИ}

1. Вороненко Ю. В. Створення системи паліативної і хоспісної допомоги в умовах реформування охорони здоров'я в Україні: медичні і соціальні аспекти [Електронний ресурс] / Ю. В. Вороненко, Ю. І. Губський, А. В. Царенко // Охорона здоров'я і суспільство. - 2014. № 1 (2). - С. 63-75.

2. Брацюнь О. П. Вплив міждисциплінарного підходу в наданні паліативної допомоги на якість життя паліативних пацієнтів (на прикладі роботи першого денного хоспісу в Україні) / О. П. Брацюнь, Г. М. Науменко // Реабілітація та паліативна медицина. - 2016. - № 1. - С. 80-83.

3. Ястремська С. О. Роль медичних сестеру паліативній (хоспісній) допомозі / С. О. Ястремська, О. С. Усинська // Медсестринство. - 2011. - № 3. - С. 4-7.
4. White Paper on standards and norms for hospice and pallianive care in Europe [Electronic resource] / Recommendations from the European Association for Palliative Care. Part I // European Journal of Palliative Care. 2009. - № 16 (6). -177 Р. 278-289.

5. Перепелиця А. Вплив здібностей на формування професійно важливих якостей майбутньої медичної сестри / А. Перепелиця // Педагогіка і психологія професійної освіти. - 2013. - № 4. - С. 203-212.

6. Овсяннікова Я. О. Самооцінка та самотність: залежність і взаємозв'язок / Я. О. Овсяннікова, Т. Ю. Довбій // Психологічні науки. - 2011. - № 58. - С. 119-122.

Отримано 10.10.17 